\title{
The role of maritime logistics and supply chain in stimulating the export of agricultural products
}

\author{
Nino Sagareishvili ${ }^{1^{*}}$ \\ ${ }^{1}$ Ivane Javakhishvili Tbilisi State University, 1 Ilia Chavchavadze Avenue, Tbilisi, Georgia
}

\begin{abstract}
The article discusses the role of sustainable transport systems in competitiveness of Georgian agri-food products. Georgian agri-food products are less competitive on international markets. The country has FTAs with its partners that should make Georgian goods more competitive, at least in terms of price. Transport and logistics is one of the main parts of export, therefore, they have an impact on competitiveness of exported goods. Georgia trades with its neighbour countries, with the EU, China, etc. The EU and China represent huge markets and Georgian government targets to increase export in both directions, but there is a long distance between Georgia and its target markets, therefore it needs a developed transport and logistics system. On the other hand, portions of exported Georgian agri-food products are primary production, which have a shorter lifetime period, that's why they should be transported in a short period of time, with specific machines. Without development of the transport system it is impossible to achieve sustainable export of agri-food products into Georgia's target markets. Investments in the system, with tangible strategy and holistic approach can create a sustainable transport system that will increase competitiveness of Georgian agri-food products in international markets.
\end{abstract}

\section{Introduction}

Development of international trade and globalized economies highly depend on the efficiency and sustainability of logistic services. There are many challenges during pandemic for international logistics and maritime industries. However, it should be mentioned that besides the challenges development of maritime industry becomes a great business opportunity [1].

Nowadays, during the globalization process can be seen that no nation is self-sufficient. It means that there are flows of goods and services, labor, technology, information and etc. $[2]$.

The global economies are characterized by integrated full package services, such as: logistics, finance, production, retail and distribution. Dr. Jean-Paul Rodrigue in his article: "Globalization and International Trade" (2020) discusses the main challenges and

\footnotetext{
'Corresponding author: n.sagareishvili@iset.ge
} 
perspective of improving transport and logistics. He states very important point that development of International trade is highly related to effective management of all elements of supply [2].

While countries are concentrating on implementation of export promotion strategies for agricultural and non-agricultural products, they have to take into account the importance of maritime logistics and effective supply chain. There is no an exact definition of maritime logistics, but Dong-Wook Song and Photis Panayides in their article: "Maritime Logistics: A New Definition" (2015) explain that maritime transport include shipping and port and is used to transport goods and passengers between different seaports by sea [3]. Logistics is defined as the overall process that a good needs to go through from the producer to get to the final consumer. These processes include: acquire, store, and transportation [4]. The management of Supply chain includes the integration of all parts of business operations across the supply chain. The main idea to discuss maritime logistics and supply chain together is to understand all key elements that are covered to get to the final consumer [3].

\section{Literature review}

Azmat Gani discusses very interesting studies about linkages of logistics and trade [1]:

1. Logistics for trade include wide range of processes to get to the final consumer (or country);

2. Goods that are crossing the border go through the administrative procedures;

3. There are needed wide range of international shipment operations [5];

4. There is needed effective supply chain management;

5. All processes are linked to each other and depend highly on effective management and planning system.

James Anderson and Douglas Marcouiller discussed main obstacles that international trade may face [6]:

1. Corruption

2. Imperfect contracting processes

4. Ineffective management system

5. Problems with maritime logistics

6. Trade barriers.

One of the determinant of trade can be assumed to be a shipping connectivity, discussed by Marco Fugazza and Jan Hoffmann. Maritime transport is one of the main transport services that is used during export of different types of good. The article underlines the importance of effective management of maritime logistics. When the process is implemented correctly, taking into account all administrative support, trade becomes easier between countries [7].

United Nations Conference on Trade and Development analysis Liner Shipping Bilateral Connectivity Index (LSBCI) with a data of different countries. The LSBCI includes the following 5 components [7].

1. The number of transshipments required to transport goods from country 1 to country 2 ;

2. The number of direct connections (for both countries);

3. The geometric mean of the number of direct connections;

4. The level of competition on services;

5. The size of the largest ships on the smallest route.

LSBCI is very important to control and monitor efficient transport services that are highly correlated with economic development. Maritime logistics is one of the main element to evaluate the competitiveness of the country in the region and in the world [7].

Georgia has favorable geographical location and has the potential to become a logistic hub of the Caucasus and Central Asia. It increases competitiveness of Georgia. 
Nowadays, Georgia highly depends on import of agricultural and non-agricultural products. Mikheil Tokmazishvili in his article: "New Challenges of Transportation of Goods through the Transport Corridor of Georgia" (2018), discusses the problems of the Georgian transport corridor, dynamics of international cargo transportation, reasons for change and prospects. It is mentioned that the further development of the Georgian transit corridor is largely depended on a "one belt - one way" strategy initiated by China [8].

The article: "Georgia as the Sea Gate of the Middle Corridor" (2019), discusses that according to 2017 data, the volume of containers (TEU) shipped between Europe and Asia is about 22 million. 15 million TEUs are shipped from China to Europe and 7 million from Europe to China. 97\% of the volume (in tons) of these cargoes and $70 \%$ of the value of these cargoes are transported by sea. Only $2 \%$ of cargo volume are transported by air [9].

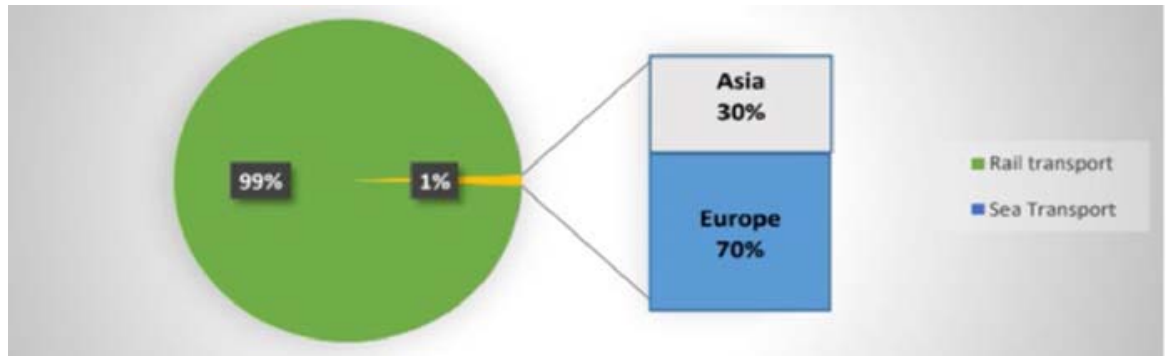

Fig. 1. Asia - Europe Container Shipping (2017) [9].

Figure 1 shows Shipping statistics during 2017. Sea transport is used in 99\% while shipping goods and just $1 \%$ uses air transportation. 30\% is transportation is from Asia and $70 \%$ from Europe [9].

The article underlines that the main challenge for Georgia is intermodal transportation. Intermodal transportation is defined as "using two (or more) carriers, to transport goods (freight) from shipper to consignee" [10]. Intermodal transportation needs special standardized containers of cargo on trucks, freight trains, and ships [10].

The following information are needed to find whether the intermodal transportation is good for agricultural goods or not [10]. It is most suitable when:

1. The country transports intermediate or finished goods and load of them is less than 25 tons.

2. Theree is a long distance between countries.

3. The cargos' value is intermediate. Cargo with high values are sent directly by air cargo (railway transportation is also possible).

4. There is a need to continuously transport goods to same location.

Intermodal transportation is important for the connectivity of the Caspian and Black Sea and for the efficiency of land container transportation (Hinterland transportation). The development of intermodal transport is an important factor in increasing the efficiency of ports and the functioning of the transport corridor as a unified logistics' network [9]. 


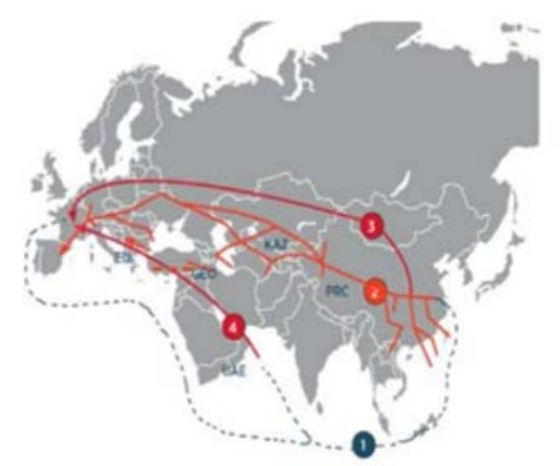

\begin{tabular}{|c|c|}
\hline $\begin{array}{c}\text { Types of } \\
\text { transport }\end{array}$ & $\begin{array}{c}\text { Time needed for } \\
\text { transportation }\end{array}$ \\
\hline Sea transport & 36 Days \\
\hline Air transport & 14 Days \\
\hline Railway & 2 Days \\
\hline Sea-air transport & 25 Days \\
\hline
\end{tabular}

Fig. 2. Asia Europe Alternative Transport Routes [9].

From the Figure 2 we can find that Georgia is the shortest maritime union for Central Asia through the Middle Corridor and is therefore one of the most important central country in the corridor. Due to its geographical advantages, Georgia can become not only a regional logistics hub in the Caucasus, but also an important Central Asian transport route and an alternative transit corridor connecting China and Europe in the long term.

Georgia's transit and logistics potential plays an important role in the development of its economy and Georgia's integration into the global market. To achieve this goal Georgia requires the systematic development of transport and logistics infrastructure, the introduction of new technologies and the application of international management practices in transport and logistics [9].

Giorgi Danelia discusses opportunities of Georgia to increase transit cargo turnover. This highly depends on regional counties' economic and trade activities. Georgia is positioned as an importer country of agricultural and non-agricultural goods, but it has a potential to become a logistic hub and concentrate on increasing domestic production, promote export, especially export of agricultural goods [11].

Agricultural sector is one of priority sector for Georgian government. Country has a potential to produce high quality agricultural products that will become competitive and take place on international market $[12,13]$.

Main Challenge is to produce high quality agricultural products with low cost and set competitive price. Georgia's agricultural sector is developing nowadays. Government tries to increase domestic production and substitute import, so that the market will be depended on locally produced goods. Import substitution and export promotion are discussed as two strategies implemented to speed economic growth, increase employment rate and make a country competitive on international market [14]. State programs that facilitate exports stimulation can be considered [14]:

1. Subsidizing;

2. Removal of barriers for international trade;

3. Attracting financial resources.

4. Export lending and insurance.

Covid-19 became one of the main obstacle of developing agricultural sector, especially it became difficult to increase domestic production and promote export.

Georgian Farmers' Association underlines the importance of self-sufficiency coefficient. High coefficient means that a country has high potential to satisfy domestic demand, low coefficient means that a country is depended on imported goods. From data 2018-2020 the lowest self-sufficiency coefficient has wheat and meat, high coefficient has: eggs, potatoes, grape. It means that Georgia has a potential to increase domestic production of last mentioned goods and promote export. Also, we have to think if is it possible to use maritime logistics while exporting these goods? [15, 16. Nowadays it is difficult to say, 
because it needs more analysis and Georgia has to work more to increase effectiveness of all logistical processes.

\section{Methodology}

To evaluate the role of maritime logistics and supply chain management to promote export of agricultural products, the following methodologies are used: methods of analysis and synthesis, quantitative and qualitative, groupings, data analysis and graphical representation of the research.

1. There were done a questionnaire to find the effect of Covid-19 on development of agricultural sector.

2. The questionnaire gives a data that is graphically analyzed.

3. Also, the research contains the analysis of connection of agricultural sector and maritime logistics.

During the last decade demand on healthy agricultural goods increases. People are motivated to eat healthy high quality goods that are produced domestically. In the modern world with technological progress, a lot of investment are made in delivery services. Also, globalization and trade liberalization processes made countries to start developing of food distribution and logistics systems.

In the article: "The Impact of the Free Trade Policy on the Production of Local Agricultural Goods", the author underlines the advantages and disadvantages of free trade. As for advantages, we can discuss elimination of trade barriers, such as tarrifs. But, there are non-tariff barriers that can be discussed as one of the main obstacles for Georgian agricultural products to become competitive on international market [17].

Such kind of non-tariff barriers are sanitary and phytosanitary measures. Low quality of products make them less attractive not only for international consumers, but for local consumers as well. New technologies and high skilled labor force can increase agricultural productivity [17].

The article: "Transport and agricultural productivity: A cross-national analysis", underlines that logistics and transport infrastructure are motivational factors to develop agriculture sector, because when the logistic process is effective, productivity increases. Countries which have such kind of benefit can specialize in the production of agricultural goods, get comparative advantage and promote export [18].

\section{Analysis}

Data is collected from the web-page of the United Nations Conference on Trade and Development. All information is discussed theoretically and graphically.

During 2019 export structure by product groups are the following [19]:

1. All food items $-23 \%$

2. Ores and metals $-20 \%$

3. Manufacturad goods $-54 \%$

4. other $-3 \%$

Analyzing UNCTAD statistical data, we can see that there is $+3.4 \%$ growth of transport services export and $+82.3 \%$ Fleet growth rate in 2019 [19]. 


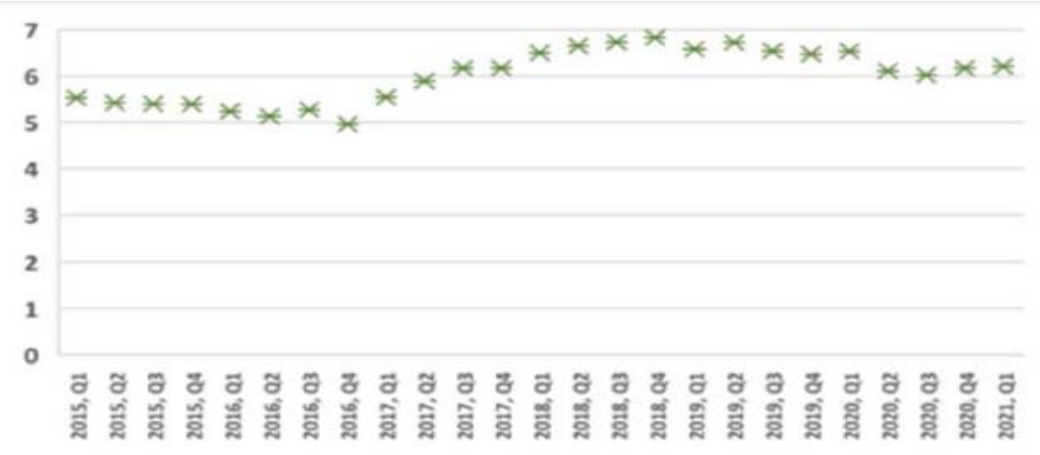

Fig. 3. Liner Shipping Bilateral Connectivity Index, Georgia [19].

Also, it is interesting to calculate LSBCI for Georgia. Analyzing data from 2015 - 2020, Georgia had decreasing tendency of LSBCI during 2015 - 2016. After that Georgia has increasing tendency till 2020. From 2020 Q1 to 2020 Q2 LSBCI decreased by $0.07 \%$. In the Q1 of 2021, Liner Shipping Bilateral Connectivity Index is 6.21 that is higher it was in 2015. It should be mentioned that the highest level was achieved in the Q4 in 2018 [20].

Analyzing World Bank statistics, we can find that world export has a reducing tendency from 2018. Maximum amount of export in the world was reached in 2018 ( $\$ 20$ trillion), in 2020 total export was approximately $\$ 17$ trillion. Also, figure 6 represents main food export groups in the world [21].

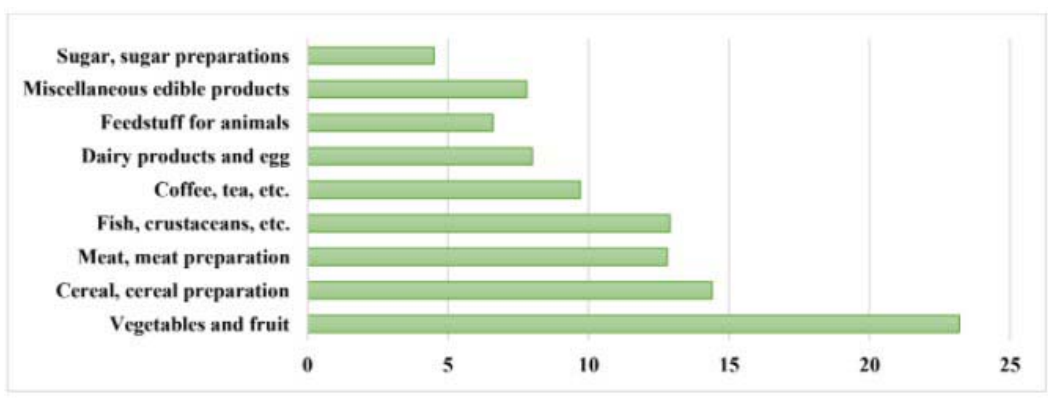

Fig. 4. Structure of food export, 2017.

According to questionnaire and the data collected by Georgian Farmers' Association, Covid-19 has a huge effect on the production of agricultural goods. These effects are discussed with different directions [15]:

1. Changes in prices (prices are increased highly during pandemic);

2. Difficulties to buy high quality and healthy products, because of Lockdown situation;

3. Increase of input prices;

4. Challenges of maritime logistics, because of regulations on economic activities;

5. People are not willing to work during pandemic;

6. First reason is Lockdown situation and regulations on transport;

7. Second reason is risk of health.

Officially $62 \%$ from the farmers and agricultural business representatives are producing goods for domestic market, only $17 \%$ export their products [15].

Also, analyzing the questionnaire, we get that $55 \%$ of agricultural business representatives have problem with supply chain. The respondents listed the main reasons of this: 
1. Imported agricultural goods became more expensive because of devaluation of GEL;

2. Challenges to attract funds during pandemic;

3. Challenges of sea transportation and administrative barriers during pandemic;

4. Deficit of domestically produced intermediate and final goods (inputs);

5. Transport regulation locally and internationally.

From the data and questionnaire analysis we can conclude that political support is very important not only to developing of agricultural sector, but also develop food shipment. Government form different countries have to be ready to open borders and eliminate barriers to stimulate export and develop logistical services [22-25]. Also, government support is very important while discussing administrative barriers of shipment.

To develop shipping infrastructure, it is very important to attract funds, to implement effective regulation system, use new technology, manage supply chain, train employees, increase quality of agricultural goods and etc.

\section{Conclusions}

Based on analysis main conclusions are made:

1. Georgia has undeveloped shipment infrastructure that is a barrier to enter the international market

2. Agricultural sector is main priority of the government, but still there is not effective, modern standards and processes of supply chain management

3. Maritime logistics in one of the main obstacle to promote agricultural good's export

4. There is not produced high quality agricultural goods in Georgia and it makes country less competitive on the international market

5. Unskilled labour force

Is would be beneficial for the country to:

1. Improve the maritime logistics that will help not only to promote agricultural goods, but will be the real proof for Georgia to become a logistic hub of the region.

2. Increase intermodal service efficiency that will be helpful to increase export of agricultural goods.

3. Manage supply chain effectively.

4. Eliminate trade barriers for agricultural good.

5. Develop strategic partnership with regional countries and also implement effective strategy to take place on developed countries' markets.

\section{References}

1. Gani, A. (2017). The Logistics Performance Effect in International Trade. The Asian Journal of Shipping and Logistics, 33(4), 279-288. https://www.sciencedirect.com/science/article/pii/S2092521217300688

2. Rodrigue, J. (2020). Globalization and International Trade. The Geography of Transport Systems. https://transportgeography.org/contents/chapter7/globalizationinternational-trade/

3. Song, D., \& Panayides, P. (2015). Maritime Logistics: A New Definition. https://www.koganpage.com/article/maritime-logistics-a-new-definition

4. Investopedia (2021). https://www.investopedia.com/terms/l/logistics.asp

5. Korinek, J., \& Sourdin, P. "To what extent are high-quality logistics services trade facilitating". OECD Trade Policy Papers, 108, OECD Publishing.

6. Anderson, J.E., \& Marcouiller, D. (2002). Insecurity and the pattern of trade: an empirical investigation. Review of Economics and Statistics, 342-352. 
7. Fugazza, M., \& Hoffmann, J. (2017). Liner shipping connectivity as determinant of trade. Journal of Shipping and Trade, 2(1).

8. Tokmazishvili, M. (2018). New Challenges of Transportation of Goods through the Transport Corridor of Georgia. http://eprints.tsu.ge

9. Doborjginidze, G. (2019). Georgia as the Sea Gate of the Middle Corridor. https://forbes.ge/saqarthvelo-rogorts-shua-de/

10. American Group. (2017). What is Intermodal Transportation and When is it the Best Choice? https://www.shipag.com

11. Danelia, G. (2019). Georgia's Container Market and The Black Sea Region. Economic Alternatives, 1, $106-116$. https://www.unwe.bg/uploads/Alternatives/8 EA 1 2019 en.pdf

12. Kharaishvili, E., \& Natsvlishvili, I. (2019). Markets for Georgian agri-food products and economic policy for export stimulation. Globalisation and Business, (8), 44-53.

13. Kharaishvili, E. (2017). Directions for improving the supply chain in the agro-food sector of Georgia.

14. Sagareishvili, N. (2019). The Role of State Programs to Stimulate Export of Local Agricultural Goods.

15. Georgian Farmers' Association. (2020). https://gfa.org.ge/wpcontent/uploads/2020/04/GFA COVID-19-IMPACT GEO-FINAL compressed-1.pdf

16. National Statistics Office of Georgia (2021). https://www.geostat.ge/en

17. Saghareishvili, M. (2019). The Impact of the Free Trade Policy on the Production of Local Agricultural Goods.

18. Liu, S. (2017). Transport and agricultural productivity: A cross-national analysis. https://www.researchgate.net/publication/314219295 Transport_and_agricultural_prod uctivity_A cross-national_analysis

19. United Nations Conference on Trade and Development. (2021). https://unctadstat.unctad.org/EN/Index.html

20. United Nations Conference on Trade and Development. https://unctadstat.unctad.org/wds/TableViewer/tableView.aspx?ReportId=92

21. World Export and Import of Agricultural Products (2021). https://knoema.com/cduhihd/world-exports-and-imports-of-agricultural-products

22. Koval, V., Duginets, G., Plekhanova, O., Antonov, A., \& Petrova, M. (2019). On the supranational and national level of global value chain management. Entrepreneurship and Sustainability Issues, 6(4), 1922-1937. http://doi.org/10.9770/jesi.2019.6.4(27)

23. Mikhno, I., Koval, V., Shvets, G., Garmatiuk, O., \& Tamošiūnienė, R. (2021). Green Economy in Sustainable Development and Improvement of Resource Efficiency. Central European Business Review, 10(1), 99-113. https://doi.org/10.18267/j.cebr.252

24. Dankeieva, O., Solomianiuk, N., Strashynska, L., Fiedotova, N., Soloviova, Y., \& Koval, V. (2021). Application of Cognitive Modelling for Operation Improvement of Retail Chain Management System. TEM Journal, 10(1), 358-367. https://doi.org/10.18421/TEM101-45

25. Tsimoshynska, O., Koval, M., Kryshtal, H., Filipishyna, L., Arsawan, W. E., \& Koval, V. (2021). Investing in road construction infrastructure projects under public-private partnership in the form of concession. Naukovyi Visnyk Natsionalnoho Hirnychoho Universytetu, 2, 184-192. https://doi.org/10.33271/nvngu/2021-2/184 